\title{
BIBLIOMETRIC ANALYSIS OF POSTGRADUATE DISSERTATIONS PUBLISHED ON THE SUBJECT OF SOCIAL ENTREPRENEURSHIP IN TOURISM: A COMPARISON OF TURKEY, THE UNITED KINGDOM AND THE UNITED STATES OF AMERICA
}

\author{
Emre Ozan Aksöz \\ İpek Itir Can \\ Ervin Mihelj
}

https://doi.org//10.20867/tosee.06.1

\begin{abstract}
The study aims to examine postgraduate dissertations in the areas of social entrepreneurship, social entrepreneurship in tourism and entrepreneurship in tourism published in Turkey, the United Kingdom, and the United States through bibliometric analysis. For this purpose, a total of 126 doctoral dissertations published between 2015-2020 were reached through Proquest Dissertations, YÖK National Dissertations Center, EThOS British Library and EBSCO Dissertations databases. The obtained dissertations were discussed in line with parameters of country where the dissertations were prepared, type of the dissertations, publication year of the dissertations, title of the dissertation's supervisor, university where the dissertations were prepared, field of study of the dissertations, and research method used in the dissertations. In conclusion, it was found that Turkey was behind the United Kingdom and the United States in terms of quantity of doctoral dissertations published about social entrepreneurship and entrepreneurship in tourism. Social entrepreneurship in tourism has been found to be a current issue that needs to be researched and has a large literature gap for all three countries.

Keywords: Bibliometric analysis, Entrepreneurship, Social entrepreneurship, The United Kingdom, The United States of America, Turkey.
\end{abstract}

\section{INTRODUCTION}

The formation of the theoretical infrastructure of the concept of entrepreneurship dates back to the 18th century, Industrial Revolution (Mort, Weerawardena and Carnegie 2002). The definition made by the economist Richard Cantillon in 1755 is accepted as the first definition of entrepreneurship in literature and is stated as "the work conducted by a person (entrepreneur) who organizes a business with the aim of making a profit and accepts the risks" (Siirt University Lecture Notes 2019). While entrepreneurship is defined by Bird (1989) as "the establishment of a new business with the aim making a profit and creating value, or development of a business and creation of new goods or services"; Mueller and Thomas (2001) define it as "the process of creating an organization in order to obtain perceived opportunities" (Yılmaz and Sünbül 2009). Although there are many different definitions of entrepreneurship in the literature, it can be summarized as "the activity of establishing or developing a business by taking risks to make a profit by realizing opportunities and making use of the opportunities in the ever-changing and developing competitive world market" (Öğ̈̈tcü 2015). The concept 
ToSEE - Tourism in Southern and Eastern Europe, Vol. 6, pp. 1-24, 2021.

E.O. Aksoz, İ.I. Can, E. Mihelj: BIBLIOMETRIC ANALYSIS OF POSTGRADUATE DISSERTATIONS...

of entrepreneurship, which encompasses taking risks, looking for opportunities, pursuing innovations and creativity, also encompasses the abilities to plan and manage the steps in the process of achieving goals (Başar 2013).

Although today the concepts of entrepreneurship and social entrepreneurship are accepted as related terms, it can be seen that until the $2000 \mathrm{~s}$, the state of being "correlative" was not much mentioned and they were considered two completely separate terms. So much so that according to Skloot (1988), the idea of non-profit entrepreneurship (this discourse refers to social entrepreneurship) and the idea of entrepreneurship together constitute the use of two completely opposite or contradictory concepts, an oxymoron. In the relevant years, the concept of social entrepreneurship, separate from today's perception, was regarded as completely non-profit-oriented organizations, and therefore was contradicted with the "goal of making a profit" which is at the heart of entrepreneurship. In other words, before the 2000 s, the concept of social entrepreneurship had the same connotation as the activities of a non-profit organization. However, in the following years, it can be seen that this understanding was opposed, and new definitions of social entrepreneurship were developed.

When the definitions of social entrepreneurship after the 2000s are examined, it can be seen that some researchers focus on social problem-solving innovation, while others emphasize the dual mission (the common use of economic and social missions) (Amini, Arasti and Bagher 2018). When the different definitions of researchers are combined, the definition "the process that involves the creative use of resources for both economic and social values" emerges. Therefore, in social entrepreneurship, commercial business principles are applied, and civil society principles are adopted, and the two management styles are blended in social enterprises (Karğin, Aktaş and Gökbunar 2018). In addition, according to Hasan (2005: 3), social entrepreneurship points to innovative activities aimed at increasing organizational efficiency and ensuring sustainability (Özdevecioğlu and Cingöz 2009).

The basic assumption of social entrepreneurship is that the basic features of entrepreneurship can be used for the benefit of society without pursuing a mission of profit. The emphasis here is that profit is not a mission; in social entrepreneurship profit is a source of motivation to be used to achieve social goals. In other words, in social entrepreneurship, which combines social benefit and profit, free market-oriented methods are adopted in the process of solving social problems (Dönmez 2020). The scope of social problems in the field of social entrepreneurship is quite wide; human rights, animal rights, education, health, poverty reduction, development, environment, agriculture, and many other fundamental problems can be considered. The goal is to undertake social transformations towards these problems.

When the literature is examined, there is an increase in studies on social entrepreneurship, especially in the last five years; on the other hand, it can be observed that there is still a very small number of social entrepreneurship studies in the field of tourism. This situation is merely an observation and remains a subject that has not been investigated scientifically. The most appropriate examination technique to investigate this issue scientifically appears as bibliometric analysis. Bibliometric analysis is an examination technique that reveals how the related literature is handled and its tendencies 
ToSEE - Tourism in Southern and Eastern Europe, Vol. 6, pp. 1-24, 2021. E.O. Aksoz, İ.I. Can, E. Mihelj: BIBLIOMETRIC ANALYSIS OF POSTGRADUATE DISSERTATIONS...

by making a statistical analysis of books, scientific journals, academic dissertations, and similar sources (Tayfun et al. 2018). Thanks to bibliometric analysis, the development processes and characteristics of scientific studies are revealed; and we can examine who studies what, where, how, when and in what way (Aydın and Aksöz 2019).

The aim of the study is to examine postgraduate dissertations published in the field of social entrepreneurship, social entrepreneurship in tourism, and entrepreneurship by using the bibliometric analysis technique with determined parameters. In the study, graduate dissertations from Turkey, the United Kingdom and the United States are discussed, thereby providing an opportunity to make a comparison between these countries.

\section{LITERATURE REVIEW}

The word "dissertation" is defined as "an argument, a scientific work prepared by students or faculty members in universities and sometimes defended in front of an exam board" in the Contemporary Dictionary by Turkish Language Association (TDK, 2020). According to Aksöz and Yücel (2020), dissertations studies are accepted as an indicator of the trends and the level of institutionalization in the relevant department and discipline. When the literature is examined, it can be seen that there are many studies on bibliometric analysis of postgraduate dissertations published in different disciplines and fields; on the other hand, it can be seen that bibliometric analyses on both "social entrepreneurship" and "social entrepreneurship in tourism and entrepreneurship" are generally carried out in the form of article scanning.

As a result of the examination of 286 articles by Granados, Hlupic, Coakes and Mohamed (2011), it was found that the United Kingdom and the United States of America dominated the field of social entrepreneurship; on the other hand, it was found that especially Southeastern Asia and Southeastern Europe had a weak command of the literature. Rey-Marti, Ribeiro-Soriano and Palacios-Marqués (2016) examined 2,922 scientific sources (articles, papers, books, book chapters, meeting notes) and determined the studies on social entrepreneurship were focused, respectively, on the fields of "business and economics, public administration, social sciences and educational sciences". In addition, in the period between 2003 and 2015, most of the work on the subject was conducted in 2012 (389) and 2014 (381); and the countries with the highest number of publications are the United States (892) and the United Kingdom (494). Similarly, Persaud, Bayon and Cartmell (2018) in their study examining 92 of the most cited articles on social entrepreneurship, revealed that the literature progressed with several core authors from the United States, England, and Canada, and was shaped around the business management discipline. In another study conducted by Dionisio (2019), the contents of the articles published on social entrepreneurship were examined and it was concluded that the studies in the field were mostly conducted in the United Kingdom, the United States of America and Canada.

Stating that the subject of social entrepreneurship has reached a certain level of "maturity" in the literature, Sassmannshausen and Volkmann (2013) found that the number of publications on social entrepreneurship increased more than twice from 2009 
ToSEE - Tourism in Southern and Eastern Europe, Vol. 6, pp. 1-24, 2021.

E.O. Aksoz, İ.I. Can, E. Mihelj: BIBLIOMETRIC ANALYSIS OF POSTGRADUATE DISSERTATIONS...

to 2011 and the H-index was quite high. Compos, Sanchis and Ejarque (2019) confirmed that there is a lot of research on social entrepreneurship; however, they found that there is no study linking economic public benefit and social entrepreneurship. Kraus, Filser, O'Dwyer and Shaw (2014) examined 5,228 citations within the scope of 129 articles in their study, which aimed to provide an overview of existing research on social entrepreneurship by using the citation analysis technique. As a result of this analysis, they grouped the sub-topics examined in the field of social entrepreneurship under five headings as "definitions and conceptual approaches, motives, personality, influence and performance, future research". Another grouping was carried out by Ferreira, Fernandes, Peres-Ortiz and Alves (2017). In the study, which uses bibliometric analysis based on cocitations, the basic theoretical features of social entrepreneurship are discussed in four perspectives as "social value, hidden well-being, internationalization, and institutionalism".

It can be seen that there are more studies investigating entrepreneurship in tourism (and related disciplines; gastronomy, food-beverage, recreation, etc.) with bibliometric analysis than studies investigating tourism and social entrepreneurship with bibliometric analysis. The reason for this is thought to be that although the topic of entrepreneurship has been discussed in the literature since the early 1800 s, social entrepreneurship came to the fore only in the late 1990 s.

Li's (2008) work is the first to examine tourism and entrepreneurship with bibliometric analysis technique. In the study, the period between 1986 and 2006 was examined and the articles connecting entrepreneurship and tourism, published in seven leading hospitality and tourism management journals were examined. Between these years, a total of 4,917 articles were published in the seven journals included in the research; but it was concluded that only 97 of them (about 2\%) referred to entrepreneurship. Accordingly, it was emphasized that more theoretical studies were needed to develop a framework specific to the field of entrepreneurship in tourism and related disciplines. The next bibliometric study dealing with tourism and entrepreneurship was conducted in 2015.

The study conducted by Solvoll, Alsos and Bulanova (2015), aimed to review and analyze the current literature on tourism entrepreneurship and to address a possible gap, thus articles published between 2000 and 2012 were examined. It was determined that a total of 40 articles were published in the period between 2000 and 2006 and 96 articles were published in the period between 2007 and 2012, thus emphasizing an increase in studies in the field of tourism and entrepreneurship. In addition, referring to Li (2008), who emphasized that the theoretical studies on tourism and entrepreneurship remained at a low level, it was stressed that although the studies in recent years have developed empirically, their theoretical foundations are still not solidified.

Fu, Okumus, $\mathrm{Wu}$ and Köseoglu (2019) reviewed 108 SSCI publications published between 1995 and 2016. As a result of the research, it was determined that studies published on tourism and entrepreneurship spread from developed countries to developing countries. In addition, it was emphasized that researchers in the field of tourism should participate in interdisciplinary research teams in projects and publications related to the subject of entrepreneurship and focus on subjects specific to individuals, 
ToSEE - Tourism in Southern and Eastern Europe, Vol. 6, pp. 1-24, 2021.

E.O. Aksoz, İ.I. Can, E. Mihelj: BIBLIOMETRIC ANALYSIS OF POSTGRADUATE DISSERTATIONS...

companies and destinations in order to investigate the complex nature of entrepreneurship. Işık, Günlü Küçükaltan, Kaygalak Çelebi, Çalkın, Enser and Çelik (2019a) examined 142 research articles using bibliometric analysis technique to examine the relationship between tourism and entrepreneurship and revealed that this relationship is gathered under three themes in related articles. These themes are listed as "small and medium-sized tourism enterprises, types of entrepreneurship, and studies on entrepreneurship in the tourism sector". Işı et al. (2019b), in another bibliometric analysis conducted on entrepreneurship in tourism, reached 96 national scale scientific works and examined them under six parameters that are "title of the publication, author name(s), year of publication, research/application area, methodology of the study (data collection method) and study result". As a result of the study, it was revealed that studies in the field of entrepreneurship in tourism started at the international level in the 1990s and gained momentum in the 2000s; and at the national level they started in the 2000s increasing after 2010. In addition, it was emphasized that the studies are generally formed around entrepreneurial characteristics, internal entrepreneurship, and female entrepreneurship.

Celebi, Pirnar and Eris (2020) accessed 20 articles in their bibliometric studies on social entrepreneurship on gastronomy tourism; and stated that most of these articles were conducted with qualitative analysis and situation analysis methods. They emphasized that the reason for this is the rarity of social entrepreneurship practices in gastronomy tourism. The authors determined six parameters for the articles they reviewed and listed them as "title of the publication, keywords, author name(s), year of publication, methodology of the study, and result of the study". Sarıbaş, Kömürcü and Akbaba (2020) examined 35 articles on social entrepreneurship in tourism accessed via national and international article databases and during this review, they made use of five parameters that are "title of the publication, author name(s), year of publication, name of the journal, and field of research". In the study, it was found that most of the research on social entrepreneurship in tourism literature focuses on the hospitality sector and tourism management and associates social entrepreneurship in tourism with sustainable tourism, responsible tourism, eco-tourism, and rural tourism. It was also emphasized that there are few publications in both international and national tourism literature linking social entrepreneurship with tourism, and therefore social entrepreneurship in tourism is an open field for new research.

As a result of conducted examinations, it has been observed that the scope of bibliometric studies in the field of social entrepreneurship is kept quite wide. On the other hand, there is no study in the field of social entrepreneurship that only examines postgraduate dissertations. In addition, it has been revealed that bibliometric studies in the field of entrepreneurship in tourism and social entrepreneurship in tourism are more limited and are handled in the form of article scanning, while postgraduate academic dissertations are not examined. Therefore, the purpose and importance of this study is to examine the postgraduate dissertations in social entrepreneurship, social entrepreneurship in tourism and entrepreneurship in tourism in terms of their bibliometric properties in the last five years (the period between 2015-2020); and to put forth a comparative table among Turkey, the United Kingdom, and the United States of America. 
ToSEE - Tourism in Southern and Eastern Europe, Vol. 6, pp. 1-24, 2021.

E.O. Aksoz, İ.I. Can, E. Mihelj: BIBLIOMETRIC ANALYSIS OF POSTGRADUATE DISSERTATIONS...

\section{METHODOLOGY}

When the etymology of the concept of bibliometry is examined, it is seen that it is a combination of the words "biblion", which means book in Ancient Greek, and "metron", which means measurement (Tonta 2009). The concept of bibliometry (Al and Coștur), which can be explained as a field of study based on counting, refers to the examination of published scientific resources (books, journals, articles, dissertations, etc.) with mathematical and statistical techniques (Pritchard 1969; cited in Yilmaz 2017). According to Diodato (1994), bibliometry is a method used in the analysis of academic research and enables the quantitative evaluation of scientific productivity. Bibliometric analysis is defined as the numerical analysis of the publications produced by individuals or institutions in a certain period, in a specific area and in a specific region, and the relations between these publications (ULAKBİM 2020). According to Koehler (2001), studies conducted with the bibliometric analysis technique are divided into four groups. These are (1) studies related to citation analysis, (2) studies related to co-citation analysis, (3) studies on the efficiency of individuals, organizations, or countries in a particular field, (4) and studies focusing on information products such as books, articles, dissertations and patents (Özköse and Gencer 2017). While citation is the use of previously produced ideas by other researchers by citing and revising in order to contribute to literature (Lluch, Velasco, Lopez and Haba 2009; Polat, et al. 2019); citation analysis is the creation of a link between the citing and cited sources (Smith, 1981; cited in Al 2008). There are two important techniques of citation analysis evaluated under bibliometric analysis and these are called bibliographic matching and co-citation. While citation of the same published material in two different sources is considered bibliographic matching; citation of two different published materials in one source is considered a co-citation (Al and Tonta 2004). Studies on the productivity of individuals, organizations, or countries in a particular field, as can be deducted from the title, come to the fore in determining and evaluating the characteristics of the various disciplines in which researchers, organizations and countries work. (Huang, Ho and Chuang 2006; Hotamışlı and Erdem 2014). Studies focusing on information products such as books, articles, academic dissertations, and patents, on the other hand, focus entirely on the contents of the publications (the research method used, keywords, etc.) (Polat et al. 2019).

As a result of examinations made in bibliometric analyses, it is aimed to obtain various findings regarding scientific communication ( $\mathrm{Al}$ and Coştur 2007; cited in Güzeller and Çeliker 2017). In other words, bibliometric analysis, a powerful tool for studying the structure and dynamics of scientific fields, is seen as an important way for researchers to better understand their areas of interest (Wang, Xu and Škare 2020). Şakar and Cerit (2013), Ulu and Akdağ (2015) and Y1lmaz (2017) emphasized that, thanks to bibliometric analyses, developments in related fields can be followed, problems and deficiencies can be identified, gaps in the literature can be found and solutions can be obtained to eliminate them (Polat, Saraçoğlu and Duman 2019). With these features, bibliometric analyses, which constitute an important road map for researchers, provide the opportunity to make the literature in a particular field statistical and makes it possible to identify trends (Kasemodel, Makishi, Souza and Silva 2016). 
ToSEE - Tourism in Southern and Eastern Europe, Vol. 6, pp. 1-24, 2021.

E.O. Aksoz, İ.I. Can, E. Mihelj: BIBLIOMETRIC ANALYSIS OF POSTGRADUATE DISSERTATIONS...

When the study is approached within the framework of Koehler's (2001) classification; it is evaluated within the scope of bibliometric analyses that examine the productivity of countries in a specific area and focus on scientific resources. The study aims to examine postgraduate dissertations published between 2015 and 2020 in Turkey, the United Kingdom, and the United States of America in the fields of social entrepreneurship, entrepreneurship in tourism and social entrepreneurship in tourism via various parameters.

There are two reasons the study includes Turkey, the United Kingdom, and the United States. The first of these being that the studies by Granados et al. (2011), Rey-Marti et al. (2016), Persaud et al. (2018) and Dionisio (2019), have the United States of America and the United Kingdom as the leading countries in the phenomenon of social entrepreneurship. The second is that among the top 15 countries with the highest number of ASHOKA fellows, which is the world's first and largest social entrepreneurship platform, the countries whose dissertations language is English are the United States (3rd) and the United Kingdom (11th). Since the official languages of the other countries in the top 15 are not English, they could not be included by the researchers. It is important to compare selected countries with Turkey.

In studies conducted with bibliometric analysis technique, determination of parameters is an issue that directly affects the findings and thus the results of the study. Thus, in the process of determining the parameters, studies published by Güçlü Nergiz (2014), Civelek Oruç and Türkay (2017), Yılmaz (2017), Aydın (2017), Sünnetçioğlu, Yalçınkaya, Olcay and Okan (2017) and Akkaşoğlu, Akyol, Ulama and Zengin (2019) that examine postgraduate dissertations in tourism and related fields with bibliometric analysis have been used. Commonly used parameters in these studies were determined as "country where the dissertations were prepared, type of the dissertations, publication year of the dissertations, title of the dissertations supervisor, university where the dissertations was prepared, field of study of the dissertations, the research method used in the dissertations," and were included in the scope of the study.

The research questions determined in line with the purpose of the study and guiding the parameters are listed as follows.

- What is the distribution of postgraduate dissertations on the related subjects across the determined countries (Turkey, the United Kingdom, and the United States)?

- What are the types of postgraduate dissertations on the related subjects?

- What is the distribution of publication years of postgraduate dissertations on the related subjects?

- What is the distribution of the titles of advisors who carry out graduate dissertations on the related subjects?

- Which universities publish postgraduate dissertations on the related subjects?

- What are the fields of study of postgraduate dissertations on the related subjects?

- What are the research methods of postgraduate dissertations on the related subjects?

In order to access the postgraduate dissertations for the study ProQuest Dissertations (international), YÖK National Dissertations Center (Turkey), EThOS British Library (United Kingdom) and EBSCO Dissertations (United States) databases were scanned. 
ToSEE - Tourism in Southern and Eastern Europe, Vol. 6, pp. 1-24, 2021.

E.O. Aksoz, İ.I. Can, E. Mihelj: BIBLIOMETRIC ANALYSIS OF POSTGRADUATE DISSERTATIONS...

The Council of Higher Education (YÖK), which gathers all higher education institutions in Turkey under its roof, is a constitutional institution established in accordance with the basic principles of the higher education system determined by the 1982 Constitution of the Republic of Turkey (YÖK 2021). In line with the "Directive on Collecting, Arranging and Making Access to Graduate Theses in Electronic Environment" prepared within the scope of the Higher Education Law in Turkey, all the theses (at master's and doctorate level) in Turkey were collected on the online platform called YÖK National Dissertations Center. On the other hand, there is no online platform that gathers both master's and doctoral theses under a single roof in the UK and the USA. In support of this, there is the following statement on the home page of EThOS British Library, the thesis center of the United Kingdom: "Search over 500,000 doctoral theses." Similarly, the statement on the homepage of EBSCO Dissertations, the thesis center of the United States, is as follows: "EBSCO Open Dissertations now includes the content from American Doctoral Dissertations." In the United Kingdom and the United States, master's theses are available in the library of the university where the thesis was published. However, as it can be understood, an online platform that combines these theses under a single roof has not been found. Therefore, the research was carried out only on doctoral theses.

After the databases to be searched were determined, the scanning was carried out by dissertations name, summary and keywords between 2 November and 13 December 2020. During the process, "search keywords" were determined by the researchers in accordance with the purpose of the dissertations. In order to understand the search keywords more easily, they are represented in Figure 1, Figure 2 and Figure 3 below, respectively.

Figure 1: Search keywords used in a bibliometric study on social entrepreneurship

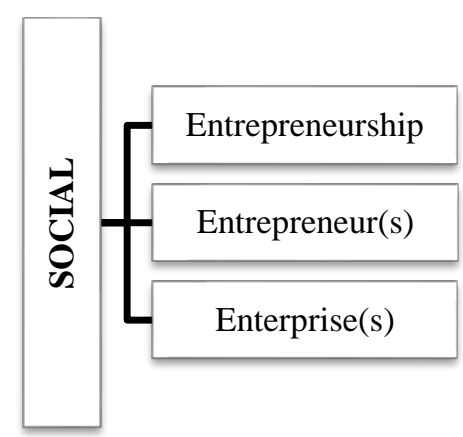


ToSEE - Tourism in Southern and Eastern Europe, Vol. 6, pp. 1-24, 2021. E.O. Aksoz, İ.I. Can, E. Mihelj: BIBLIOMETRIC ANALYSIS OF POSTGRADUATE DISSERTATIONS...

Figure 2: Search keywords used in a bibliometric study on social entrepreneurship in tourism
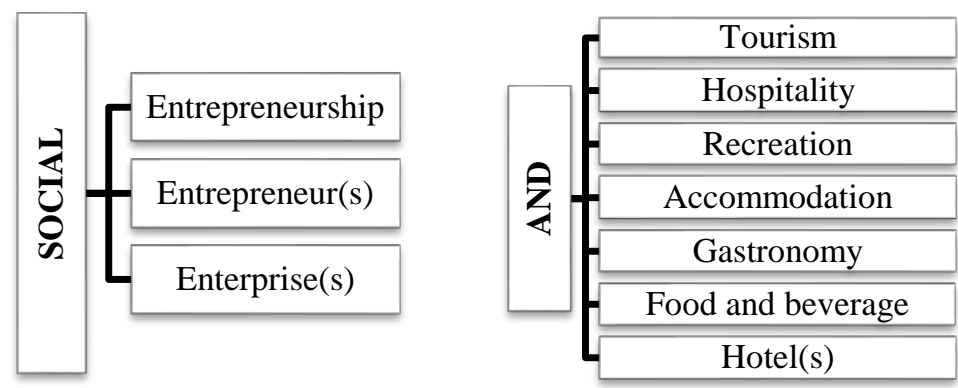

Figure 3: Search keywords used in bibliometric study on entrepreneurship in tourism
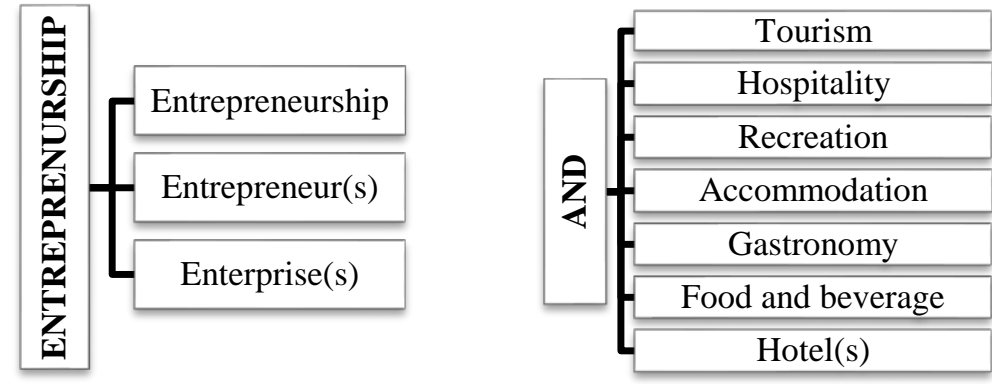

After determining the parameters, databases, and search keywords; a detailed research has been made through databases and as a result, 134 in the field of social entrepreneurship; 9 in social entrepreneurship and tourism; and 41 in the field of entrepreneurship and tourism, have been accessed with a total of 184 postgraduate dissertations. The obtained dissertations were transferred to the Microsoft Excel file in accordance with the parameters and the analysis process were commenced.

\section{FINDINGS}

In the process of doing research through data bases, it was observed that the United Kingdom and the United States, do not have an infrastructure similar to the YÖK National Dissertations Center in Turkey. While it was possible to reach both postgraduate dissertations and doctoral dissertations published in Turkey via YÖK National Dissertations Center; it was been observed that the number of postgraduate dissertations uploaded to Proquest Dissertations, EThOS British Library and EBSCO Dissertations databases was almost nonexistent. As a result, other databases to access post graduate dissertations were researched; but could not be found. For this reason, in the study, first a table showing the distribution of both postgraduate and doctoral dissertations was included, and then the comparisons were only made on the doctoral 
ToSEE - Tourism in Southern and Eastern Europe, Vol. 6, pp. 1-24, 2021. E.O. Aksoz, İ.I. Can, E. Mihelj: BIBLIOMETRIC ANALYSIS OF POSTGRADUATE DISSERTATIONS...

dissertations. The findings of the study, on the other hand, are examined under three headings: "social entrepreneurship", "social entrepreneurship in tourism" and "entrepreneurship in tourism".

\subsection{Bibliometric Analysis Findings on Social Entrepreneurship}

The distribution of the types of completed postgraduate dissertations in the field of social entrepreneurship in Turkey, the United Kingdom and the United States are shown on Table 1 below.

Table 1: Distribution of Postgraduate Dissertations in the Field of Social Entrepreneurship by Type and Country

\begin{tabular}{lrrrrrr}
\hline & PhD (n) & PhD (\%) & $\begin{array}{r}\text { Master's } \\
\text { Degree (n) }\end{array}$ & $\begin{array}{r}\text { Master's } \\
\text { Degree (\%) }\end{array}$ & Total (n) & Total (\%) \\
\hline TR & 6 & $6 \%$ & 36 & $100 \%$ & 42 & $31 \%$ \\
UK & 46 & $47 \%$ & - & $0 \%$ & 46 & $34 \%$ \\
USA & 46 & $47 \%$ & - & $0 \%$ & 46 & $34 \%$ \\
\hline Total & 98 & $100 \%$ & 36 & $100 \%$ & 134 & $100 \%$ \\
\hline
\end{tabular}

As seen on Table 1, postgraduate level dissertations could not be accessed for the United Kingdom and the United States of America. While between 2015 and 2020, 46 each doctoral dissertation on social entrepreneurship were published in the United Kingdom and the United States; in the same period 6 doctoral dissertations and 36 postgraduate dissertations were published in Turkey. Since it is thought that postgraduate dissertations will reduce objectivity in comparisons, subsequent interpretations will only encompass 98 doctoral dissertations.

The distribution of doctoral dissertations published in Turkey, the United Kingdom and the United States per year can be found on Table 2 below.

Table 2: Distribution of Doctoral Dissertations in the Field of Social Entrepreneurship by Year and Country

\begin{tabular}{lrrrrr}
\hline & TR (n) & UK (n) & USA (n) & Total (n) & Total (\%) \\
\hline 2015 & 1 & 2 & - & 3 & $3 \%$ \\
2016 & 1 & 15 & 11 & 27 & $28 \%$ \\
2017 & - & 8 & 9 & 17 & $17 \%$ \\
2018 & - & 10 & 12 & 22 & $22 \%$ \\
2019 & 2 & 6 & 7 & 15 & $15 \%$ \\
2020 & 2 & 5 & 7 & 14 & $14 \%$ \\
\hline Total & 6 & 46 & 46 & 98 & $100 \%$ \\
\hline
\end{tabular}

When a review was conducted in the scope of years, it was seen that the year most dissertations were published was 2016 with 27 dissertations (28\%), followed by 2018 with 22 dissertations (22\%). The least number of dissertations were published in 2015, with just three (3\%). The years most dissertations were published in Turkey are 2019 and 2020; 2016 for the United Kingdom; and 2018 for the United States. 
ToSEE - Tourism in Southern and Eastern Europe, Vol. 6, pp. 1-24, 2021.

E.O. Aksoz, İ.I. Can, E. Mihelj: BIBLIOMETRIC ANALYSIS OF POSTGRADUATE DISSERTATIONS...

When it comes to the titles of the advisors managing the examined doctoral dissertations, it is striking that the tradition of co-advisors is high in the United Kingdom and the United States of America, so the number of dissertations with two different titles is high. Table 3 below includes the distribution of academic titles for dissertations advisors.

Table 3: Distribution of Doctoral Dissertations in the Field of Social Entrepreneurship by Advisor Title and Country

\begin{tabular}{lrrrrr}
\hline & TR & UK & USA & Total & Total \\
$(\%)$ & $(n)$ & $(n)$ & $\begin{array}{r}\text { Th } \\
(\%)\end{array}$ \\
\hline Professor Doctor & 6 & 13 & 22 & 41 & $42 \%$ \\
Doctor & - & 13 & 7 & 20 & $20 \%$ \\
Professor Doctor \& Doctor & - & 11 & 1 & 12 & $12 \%$ \\
Associate Professor & - & 2 & 9 & 11 & $11 \%$ \\
Assistant Professor & - & - & 6 & 6 & $6 \%$ \\
Professor Doctor \& Associate & - & 3 & 1 & 4 & $4 \%$ \\
Professor & - & 3 & - & 3 & $3 \%$ \\
Missing Data & - & 1 & - & 1 & $1 \%$ \\
Associate Professor \& Doctor & 6 & 46 & 46 & 98 & $100 \%$ \\
\hline Total & & &
\end{tabular}

As seen on Table 3, of 98 doctoral dissertations $42 \%$ were advised by a professor doctor; $20 \%$ were advised by a doctor; $12 \%$ by a professor doctor and a doctor; and $11 \%$ were advised by a faculty member with the title of associate professor. Dissertations conducted under the counselling of an associate professor and a doctor showed the least distribution with $1 \%$. While in Turkey all published these were advised by a faculty member with the title of professor doctor; it was determined that in the United Kingdom over half of the dissertations $(56 \%)$ were advised by a professor doctor $(28 \%)$ and a doctor $(28 \%)$. For the United States of America, it was determined that almost half (48\%) of the dissertations were advised by a faculty member with the title professor doctor.

In the United Kingdom and the United States institutes that publish the dissertations don't have a clear distinction such as, Social Sciences/Science/Education Sciences in Turkey. The distribution here is much more complex, and each university has a specifically named school/college. Due to this difference, it was thought that it was difficult to categorize the institutes where the dissertations were published, and the dissertations were grouped according to their fields of study depending on the departments. The study areas of doctoral dissertations published in the field of social entrepreneurship can be examined on Table 4 below. 
ToSEE - Tourism in Southern and Eastern Europe, Vol. 6, pp. 1-24, 2021. E.O. Aksoz, İ.I. Can, E. Mihelj: BIBLIOMETRIC ANALYSIS OF POSTGRADUATE DISSERTATIONS...

Table 4: Distribution of Doctoral Dissertations in the Field of Social Entrepreneurship by Study Field and Country

\begin{tabular}{lrrrrr}
\hline & TR & UK & USA & Total (n) & Total (\%) \\
\hline Management and Business & 4 & 35 & 18 & 57 & $58 \%$ \\
Education & 1 & 4 & 18 & 23 & $23 \%$ \\
Communication Sciences & - & 2 & 1 & 3 & $3 \%$ \\
Policy Studies & - & - & 2 & 2 & $2 \%$ \\
Psychology & - & 1 & 1 & 2 & $2 \%$ \\
Sociology & - & 1 & 1 & 2 & $2 \%$ \\
Labor Economics and Industrial Relations & 1 & - & - & 1 & $1 \%$ \\
Anthropology & - & 1 & - & 1 & $1 \%$ \\
Philanthropy Studies & - & - & 1 & 1 & $1 \%$ \\
Law & - & 1 & - & 1 & $1 \%$ \\
Theology & - & - & 1 & 1 & $1 \%$ \\
Marketing & - & - & 1 & 1 & $1 \%$ \\
Social services & - & - & 1 & 1 & $1 \%$ \\
Community Health & - & - & 1 & 1 & $1 \%$ \\
International Relations & - & 1 & - & 1 & $1 \%$ \\
\hline Total & 6 & 46 & 46 & 98 & $100 \%$ \\
\hline
\end{tabular}

The fields of study were determined based on the department for which the dissertations were written and the content of the dissertations. In this context, the fields of study of doctoral dissertations are categorized under 15 main headings. Business is the most published field with $58 \%$, followed by education with $23 \%$. In other words, $82 \%$ of the fields of study on social entrepreneurship are business management and education. In Turkey there are four business management and one education fields of study; in the UK, there are 35 business management and four education fields of study. In the United States of America, it is seen that there is an equality in the fields of business management and education and 18 each dissertation has been written in both fields. The distribution of doctoral dissertations on social entrepreneurship based on research methods published in Turkey, the United Kingdom and the United States can be found on Table 5 below.

Table 5: Distribution of Doctoral Dissertations in the Field of Social Entrepreneurship by Research Method and Country

\begin{tabular}{lrrrrr}
\hline & TR & UK & USA & Total (n) & Total (\%) \\
\hline Qualitative & 1 & 43 & 32 & 76 & $78 \%$ \\
Quantitative & 4 & 2 & 8 & 14 & $14 \%$ \\
Mixed & 1 & 1 & 6 & 8 & $8 \%$ \\
\hline Total & 6 & 46 & 46 & 98 & $100 \%$ \\
\hline
\end{tabular}

When the methods used in doctoral dissertations in the field of social entrepreneurship are examined, it is seen that $78 \%$ was written with the qualitative, $14 \%$ with the quantitative and $8 \%$ with the mixed method. It is thought that the dominance of qualitative research methods is due to the difficulty of reaching the sample size suitable for the quantitative method in the newly developing field of social entrepreneurship. 
ToSEE - Tourism in Southern and Eastern Europe, Vol. 6, pp. 1-24, 2021.

E.O. Aksoz, İ.I. Can, E. Mihelj: BIBLIOMETRIC ANALYSIS OF POSTGRADUATE DISSERTATIONS...

In the distribution of research methods according to universities, most of the distribution is $1 \%$ due to the existence of a total of 77 universities. Table 6 below includes 15 universities with a distribution of over $1 \%$ according to research methods.

Table 6: Distribution of Doctoral Dissertations in the Field of Social Entrepreneurship by Research Method and University Name

\begin{tabular}{|c|c|c|c|c|c|}
\hline & $\begin{array}{r}\text { Mixed } \\
(\mathrm{n})\end{array}$ & $\begin{array}{r}\text { Quantitative } \\
\text { (n) }\end{array}$ & $\begin{array}{r}\text { Qualitative } \\
\text { (n) }\end{array}$ & $\begin{array}{r}\text { Total } \\
\text { (n) }\end{array}$ & $\begin{array}{r}\text { Total } \\
(\%)\end{array}$ \\
\hline $\begin{array}{l}\text { University of Pennsylvania } \\
\text { (USA) }\end{array}$ & - & - & 4 & 4 & $4 \%$ \\
\hline Capella University (USA) & - & - & 2 & 3 & $3 \%$ \\
\hline $\begin{array}{l}\text { University of Nottingham } \\
\text { (UK) }\end{array}$ & - & 1 & 2 & 3 & $3 \%$ \\
\hline Durham University (UK) & - & - & 3 & 3 & $3 \%$ \\
\hline Walden University (USA) & - & - & 3 & 3 & $3 \%$ \\
\hline $\begin{array}{l}\text { Cardiff Metropolitan } \\
\text { University (UK) }\end{array}$ & 1 & - & 1 & 2 & $2 \%$ \\
\hline $\begin{array}{l}\text { Northwestern University } \\
\text { (USA) }\end{array}$ & - & 1 & 1 & 2 & $2 \%$ \\
\hline Saint Louis University (USA) & - & & 2 & 2 & $2 \%$ \\
\hline University of Essex (UK) & - & 1 & 1 & 2 & $2 \%$ \\
\hline University of Exeter (UK) & - & - & 2 & 2 & $2 \%$ \\
\hline $\begin{array}{l}\text { University of Huddersfield } \\
\text { (UK) }\end{array}$ & - & - & 2 & 2 & $2 \%$ \\
\hline University of London (UK) & - & - & 2 & 2 & $2 \%$ \\
\hline Northumbria University (UK) & - & - & 2 & 2 & $2 \%$ \\
\hline $\begin{array}{l}\text { University of San Diego } \\
\text { (USA) }\end{array}$ & 1 & - & 1 & 2 & $2 \%$ \\
\hline $\begin{array}{l}\text { University of Southern } \\
\text { California (USA) }\end{array}$ & 1 & - & 1 & 2 & $2 \%$ \\
\hline
\end{tabular}

The University of Pennsylvania and Walden University are the two universities in the United States where studies published in the field of social entrepreneurship within the universities are carried out through qualitative methods. Durham University, Exeter University, Huddersfield University, University of London, and Northumbria University are universities in the United Kingdom where studies published in the field of social entrepreneurship are carried out with qualitative methods. In addition, Northwestern University in the United States of America, the University of Nottingham in the United Kingdom, and the University of Essex are among the few universities that have conducted studies in the quantitative field. Cardiff Metropolitan University in the United Kingdom and the University of San Diego and the University of Southern California in the United States are among the universities that carry out their studies through the mixed method. 
ToSEE - Tourism in Southern and Eastern Europe, Vol. 6, pp. 1-24, 2021. E.O. Aksoz, İ.I. Can, E. Mihelj: BIBLIOMETRIC ANALYSIS OF POSTGRADUATE DISSERTATIONS...

\subsection{Bibliometric Analysis Findings on Social Entrepreneurship in Tourism}

The distribution of the types of postgraduate dissertations in the field of social entrepreneurship in tourism completed in Turkey, the United Kingdom and the United States can be seen on Table 7 below.

Table 7: Distribution of Postgraduate Dissertations on Social Entrepreneurship in Tourism by Type and Country

\begin{tabular}{lrrrrrr}
\hline & PhD (n) & PhD (\%) & $\begin{array}{r}\text { Master's } \\
\text { degree (n) }\end{array}$ & $\begin{array}{r}\text { Master's } \\
\text { degree }(\%)\end{array}$ & Total (n) & Total (\%) \\
\hline TR & 1 & $25 \%$ & 5 & $100 \%$ & 6 & $67 \%$ \\
UK & 2 & $50 \%$ & 0 & $0 \%$ & 2 & $22 \%$ \\
USA & 1 & $25 \%$ & 0 & $0 \%$ & 1 & $11 \%$ \\
\hline Total & 4 & $100 \%$ & 5 & $100 \%$ & 9 & $100 \%$ \\
\hline
\end{tabular}

As seen in Table 1, postgraduate level dissertations could not be accessed for the United Kingdom and the United States of America. Two doctoral dissertations on social entrepreneurship in tourism were published in the United Kingdom and one in the United States between 2015-2020; while one doctoral level and five postgraduate level dissertations were published in the same period in Turkey. Since it is thought that dissertations at postgraduate level will reduce objectivity in comparisons, subsequent interpretations will be made over four doctoral dissertations only. The distribution of doctoral dissertations published in Turkey, the United Kingdom, and the United States per year of can be found on Table 8 below.

Table 8: Distribution of Doctoral Dissertations on Social Entrepreneurship in Tourism by Year and Country

\begin{tabular}{lrrrrr}
\hline & TR (n) & UK (n) & USA (n) & Total (n) & Total (\%) \\
\hline 2015 & - & 1 & - & 1 & $25 \%$ \\
2016 & - & - & - & - & $0 \%$ \\
2017 & 1 & & 1 & 2 & $50 \%$ \\
2018 & - & 1 & - & 1 & $25 \%$ \\
2019 & - & - & - & - & $0 \%$ \\
2020 & - & - & - & - & $0 \%$ \\
\hline Total & 1 & 2 & 1 & 4 & $100 \%$ \\
\hline
\end{tabular}

When a review was conducted in terms of years, it was seen that the year where the most dissertations were published in the field of social entrepreneurship in tourism was 2017 with two dissertations $(50 \%)$, followed by 2015 and 2018 with one dissertation each $(25 \%)$. No doctoral dissertations on social entrepreneurship in tourism could be accessed for 2016, 2019 and 2020. One each dissertation was published in Turkey and in the United States in 2017; one each doctoral dissertation was published in the United Kingdom in 2015 and 2018. Table 9 below presents the distribution of academic titles for dissertations advisors. 
ToSEE - Tourism in Southern and Eastern Europe, Vol. 6, pp. 1-24, 2021. E.O. Aksoz, İ.I. Can, E. Mihelj: BIBLIOMETRIC ANALYSIS OF POSTGRADUATE DISSERTATIONS...

Table 9: Distribution of Doctoral Dissertations in the Field of Social Entrepreneurship in Tourism by Advisor Title and Country

\begin{tabular}{lrrrrr}
\hline & TR $(\mathrm{n})$ & UK $(\mathrm{n})$ & USA (n) & Total (n) & Total $(\%)$ \\
\hline Professor Doctor & 1 & 1 & - & 2 & $50 \%$ \\
Associate Professor & - & - & 1 & 1 & $25 \%$ \\
Missing Data & - & 1 & - & 1 & $25 \%$ \\
\hline Total & 1 & 2 & 1 & 4 & $100 \%$ \\
\hline
\end{tabular}

As can be seen on Table 9, 50\% of the four doctoral dissertations published in the field of social entrepreneurship in tourism were conducted under the consultancy of faculty members with the title of professor doctor and $25 \%$ with the title of associate professor. In addition, the advisor information of a dissertations published in the United Kingdom could not be reached.

In the United Kingdom and the United States institutes where the dissertations are published don't have a clear distinction such as Social Sciences/Science/Education Science in Turkey. The distribution here is much more complex, and each university has a specifically named school/college. Due to this difference, it was thought that it was difficult to categorize the institutes where the dissertations were published, and the dissertations were grouped according to their fields of study depending on the departments. The study fields of doctoral dissertations published in the field of social entrepreneurship can be examined on Table 10 below.

Table 10: Distribution of Doctoral Dissertations on Social Entrepreneurship in Tourism by Study Field and Country

\begin{tabular}{lrrrrr}
\hline & TR & UK & USA & Total (n) & Total (\%) \\
\hline Tourism Industry (General) & 1 & 1 & - & 2 & $50 \%$ \\
Recreation, Volunteer Tourism & - & 1 & - & 1 & $25 \%$ \\
Cultural Heritage & - & - & 1 & 1 & $25 \%$ \\
\hline Total & 1 & 2 & 1 & 4 & $100 \%$ \\
\hline
\end{tabular}

The fields of study were determined based on the department in which the dissertations were written and the content of the dissertations. In this context, the fields of study of doctoral dissertations are categorized under three main headings. In dissertations on the tourism sector (general), the tourism sector stakeholders - both hotel businesses and travel agencies - are discussed together. While the dissertations dealing with the tourism sector from a general perspective have a share of $50 \%$; dissertations on recreation and volunteer tourism and in the field of cultural heritage each have a $25 \%$ share. One each dissertation on the tourism sector (general) can be found in Turkey and in the United Kingdom. In addition, the study on recreation and volunteer tourism was published in the United Kingdom and the study in the field of cultural heritage was published in the United States of America.

Distribution of doctoral dissertations on social entrepreneurship according to research method in Turkey, the United Kingdom, and the United States of America, is available on Table 11 below. 
ToSEE - Tourism in Southern and Eastern Europe, Vol. 6, pp. 1-24, 2021. E.O. Aksoz, İ.I. Can, E. Mihelj: BIBLIOMETRIC ANALYSIS OF POSTGRADUATE DISSERTATIONS...

Table 11: Distribution of Doctoral Dissertations on Social Entrepreneurship in Tourism by Research Method and Country

\begin{tabular}{lrrrrr}
\hline & TR & UK & USA & Total (n) & Total (\%) \\
\hline Qualitative & - & 1 & 1 & 2 & $50 \%$ \\
Quantitative & 1 & - & - & 1 & $25 \%$ \\
Mixed & - & 1 & - & 1 & $25 \%$ \\
\hline Total & 1 & 2 & 1 & 4 & $100 \%$ \\
\hline
\end{tabular}

When the methods used in doctoral dissertations in the field of social entrepreneurship are examined, it is seen that $50 \%$ of them use the qualitative, $25 \%$ use the quantitative and $25 \%$ use the mixed method. While in Turkey the quantitative method is preferred, qualitative and mixed methods are preferred in the United Kingdom, and in the United States of America qualitative method is preferred.

The distribution of research methods according to university can be seen on Table 12 below.

Table 12: Distribution of Doctoral Dissertations in the Field of Social Entrepreneurship by Research Method and University Name

\begin{tabular}{|c|c|c|c|c|c|}
\hline & $\begin{array}{r}\text { Mixed } \\
(\mathrm{n})\end{array}$ & $\begin{array}{r}\text { Quantitative } \\
(\mathrm{n})\end{array}$ & $\begin{array}{r}\text { Qualitative } \\
\text { (n) }\end{array}$ & $\begin{array}{r}\text { Total } \\
(\mathrm{n})\end{array}$ & $\begin{array}{r}\text { Total } \\
(\%)\end{array}$ \\
\hline $\begin{array}{l}\text { Akdeniz University } \\
\text { (TR) }\end{array}$ & - & 1 & - & 1 & $25 \%$ \\
\hline $\begin{array}{l}\text { Canterbury Christ } \\
\text { Church University (UK) }\end{array}$ & - & - & 1 & 1 & $25 \%$ \\
\hline $\begin{array}{l}\text { Purdue University } \\
\text { (USA) }\end{array}$ & - & - & 1 & 1 & $25 \%$ \\
\hline $\begin{array}{l}\text { University of Surrey } \\
\text { (UK) }\end{array}$ & 1 & - & - & 1 & $25 \%$ \\
\hline Total & 1 & 1 & 1 & 4 & $100 \%$ \\
\hline
\end{tabular}

In Turkey the dissertations on social entrepreneurship in tourism was conducted using quantitative research method at the Akdeniz University. In the United Kingdom, the dissertations using the mixed research method was published at the University of Surrey and the dissertations using the qualitative research method was published at the Canterbury Christ Church University. Finally, a dissertation on social entrepreneurship in tourism, using qualitative research method, was published in the United States of America at Purdue University.

The study was started with the aim of comparing the dissertations on social entrepreneurship in tourism and social entrepreneurship in other fields. However, since the number of doctoral dissertations on social entrepreneurship in tourism was quite limited, it was decided to evaluate entrepreneurship in tourism through bibliometric analysis and the scope of the study was expanded accordingly. 
ToSEE - Tourism in Southern and Eastern Europe, Vol. 6, pp. 1-24, 2021. E.O. Aksoz, İ.I. Can, E. Mihelj: BIBLIOMETRIC ANALYSIS OF POSTGRADUATE DISSERTATIONS...

\subsection{Bibliometric Analysis Findings on Entrepreneurship in Tourism}

The distribution of the types of postgraduate dissertations completed in the field of entrepreneurship in tourism in Turkey, the United Kingdom and the United States of America is presented on Table 13 below.

Table 13: Distribution of Postgraduate Dissertations on Entrepreneurship in Tourism by Type and Country

\begin{tabular}{lrrrrrr}
\hline & PhD (n) & PhD (\%) & $\begin{array}{r}\text { Master's } \\
\text { Degree (n) }\end{array}$ & $\begin{array}{r}\text { Master's } \\
\text { Degree }(\%)\end{array}$ & Total (n) & Total (\%) \\
\hline TR & 2 & $8 \%$ & 14 & $82 \%$ & 42 & $39 \%$ \\
UK & 11 & $46 \%$ & 1 & $6 \%$ & 46 & $29 \%$ \\
USA & 11 & $46 \%$ & 2 & $12 \%$ & 46 & $32 \%$ \\
\hline Total & 24 & $100 \%$ & 17 & $100 \%$ & 134 & $100 \%$ \\
\hline
\end{tabular}

As can be seen on Table 13, the number of dissertations at the postgraduate level that can be reached in the United Kingdom and the United States of America is very limited. Between the years 2015-2020 in Turkey 14 postgraduate and two doctoral dissertations could be reached on entrepreneurship in tourism; in the United Kingdom one postgraduate and 11 doctoral dissertations could be reached on entrepreneurship in tourism; and in the United States of America, two postgraduate dissertations and 11 doctoral dissertations could be reached on entrepreneurship in tourism. Since it is thought that postgraduate dissertations will decrease the objectivity in the comparisons, the following findings will be interpreted in the scope of 24 doctoral dissertations. The distribution of doctoral dissertations published in Turkey, the United Kingdom and the United States of America by year is given on Table 14 below.

Table 14: Distribution of Doctoral Dissertations on Entrepreneurship in Tourism by Year and Country

\begin{tabular}{rrrrrr}
\hline & TR (n) & UK (n) & USA (n) & Total (n) & Total (\%) \\
\hline 2015 & - & 7 & - & 7 & $29 \%$ \\
2016 & - & - & 4 & 4 & $17 \%$ \\
2017 & - & 2 & 2 & 4 & $17 \%$ \\
2018 & - & 2 & 1 & 3 & $13 \%$ \\
2019 & 1 & - & 3 & 4 & $17 \%$ \\
2020 & 1 & - & 1 & 2 & $8 \%$ \\
\hline Total & 2 & 11 & 11 & 24 & $100 \%$ \\
\hline
\end{tabular}

When an examination is made within the scope of years, it is seen that the year where the most dissertations were published was 2015 with seven dissertations (29\%) and all dissertations in that year were published in the United Kingdom. After that, the years 2016, 2017 and 2019 come with four each dissertation (17\% share each). The year with least dissertations published is 2020 with 1 dissertation (8\%).

When it comes to the titles of the advisors managing the examined doctoral dissertations, it is striking that the tradition of co-advisors is high in the United Kingdom and the 
ToSEE - Tourism in Southern and Eastern Europe, Vol. 6, pp. 1-24, 2021. E.O. Aksoz, İ.I. Can, E. Mihelj: BIBLIOMETRIC ANALYSIS OF POSTGRADUATE DISSERTATIONS...

United States of America, so the number of dissertations with two different titles is high. Table 15 below includes the distribution of academic titles for dissertations advisors.

Table 15: Distribution of Doctoral Dissertations in the Field of Entrepreneurship in Tourism by Advisor Title and Country

\begin{tabular}{|c|c|c|c|c|c|}
\hline & $\begin{array}{l}\text { TR } \\
(\mathrm{n})\end{array}$ & $\begin{array}{r}\mathrm{UK} \\
(\mathrm{n})\end{array}$ & $\begin{array}{r}\text { USA } \\
(n)\end{array}$ & $\begin{array}{r}\text { Total } \\
(\mathrm{n})\end{array}$ & $\begin{array}{r}\text { Total } \\
(\%)\end{array}$ \\
\hline Professor Doctor & 1 & 3 & 5 & 9 & $38 \%$ \\
\hline Associate Professor & 1 & - & 3 & 4 & $17 \%$ \\
\hline Doctor & - & 2 & 1 & 3 & $13 \%$ \\
\hline Professor Doctor \& Doctor & - & 3 & - & 3 & $13 \%$ \\
\hline Professor Doctor \& Associate Professor & - & 2 & - & 2 & $8 \%$ \\
\hline $\begin{array}{l}\text { Associate Professor \& Assistant } \\
\text { Professor }\end{array}$ & - & - & 1 & 1 & $4 \%$ \\
\hline Professor Doctor \& Associate Professor & - & - & 1 & 1 & $4 \%$ \\
\hline Missing Data & - & 1 & - & 1 & $4 \%$ \\
\hline Total & 2 & 11 & 11 & 24 & $100 \%$ \\
\hline
\end{tabular}

As seen in Table 15, 38\% of 24 doctoral dissertations were advised by a professor doctor; and $17 \%$ were advised by faculty members with the title of associate professor. This is followed by dissertations advised by faculty members with the title of doctor, and coadvised by a professor doctor and a doctor, with a $13 \%$ share each.

The fields of study of doctoral dissertations published in the field of entrepreneurship in tourism have been determined based on the department in which the dissertations are written and the content of the dissertations and can be seen on Table 16 below.

Table 16: Distribution of Doctoral Dissertations on Entrepreneurship in Tourism by Field of Study and Country

\begin{tabular}{lrrrrr}
\hline & TR & UK & USA & Total (n) & Total (\%) \\
\hline Destination & 1 & 5 & 4 & 10 & $42 \%$ \\
Accommodation & - & 3 & 2 & 5 & $21 \%$ \\
Hospitality & - & - & 2 & 2 & $8 \%$ \\
Women's Studies & - & 2 & - & 2 & $8 \%$ \\
Entrepreneurship & 1 & - & 1 & 2 & $8 \%$ \\
Rural Tourism & - & - & 1 & 1 & $4 \%$ \\
Tourism Sociology & - & - & 1 & 1 & $4 \%$ \\
Food and Beverage & - & 1 & - & 1 & $4 \%$ \\
\hline Total & 2 & 11 & 11 & 24 & $100 \%$ \\
\hline
\end{tabular}

The fields of study of doctoral dissertations on entrepreneurship in tourism are categorized under eight main headings. Destination is the field with the most publications with $42 \%$, followed by the accommodation sector with $21 \%$. In other words, $63 \%$ of the fields of study on entrepreneurship in tourism are destination and accommodation sector fields. In the field of destination and entrepreneurship, one doctoral dissertation was published in Turkey, five in the United Kingdom, and four doctoral dissertations were published in the United States of America. In the hospitality industry and the field of entrepreneurship, while there are no 
ToSEE - Tourism in Southern and Eastern Europe, Vol. 6, pp. 1-24, 2021. E.O. Aksoz, İ.I. Can, E. Mihelj: BIBLIOMETRIC ANALYSIS OF POSTGRADUATE DISSERTATIONS...

doctoral dissertations published in Turkey, three dissertations were published in the United Kingdom and two in the United States of America. The fields of study, which have a share of $8 \%$ in the distribution, are listed as the hospitality industry, women's studies, and entrepreneurship education. Rural tourism, tourism sociology and the food and beverage sector fields of study have the lowest ratio in the distribution with $4 \%$.

The distribution of doctoral dissertations published in Turkey, the United Kingdom and the United States of America on entrepreneurship in tourism according to research method is given in Table 17 below.

Table 17: Distribution of Doctoral Dissertations in the Field of Entrepreneurship in Tourism by Research Method and Country

\begin{tabular}{lrrrrr}
\hline & TR & UK & USA & Total (n) & Total (\%) \\
\hline Qualitative & - & 8 & 9 & 17 & $71 \%$ \\
Mixed & 1 & 2 & 1 & 4 & $17 \%$ \\
Quantitative & - & 1 & 1 & 2 & $8 \%$ \\
Geographic Information Systems & 1 & - & - & 1 & $4 \%$ \\
\hline Total & 2 & 11 & 11 & 24 & $100 \%$ \\
\hline
\end{tabular}

When the methods used in the doctoral dissertations in the field of entrepreneurship in tourism are examined, it is seen that $71 \%$ is written with the qualitative method, $17 \%$ with the mixed method, $8 \%$ with the quantitative method and $4 \%$ is written through geographic information systems. In Turkey one each dissertation written using the mixed method and the geographical information system; in the United Kingdom eight dissertations written with the qualitative method, two with the mixed method and one dissertation written with the quantitative method; in the United States of America, nine doctoral dissertations written with the qualitative method and one each dissertation written with the mixed and quantitative methods were reached.

There are 22 universities in total in the three countries where doctoral dissertations on tourism entrepreneurship were published. The universities with dissertations written in the field of entrepreneurship in tourism and where the distribution is more than one can be found on Table 18 below.

Table 18: Distribution of Doctoral Dissertations in the Field of Entrepreneurship in Tourism by Research Method and University Name

\begin{tabular}{lrrrrr}
\hline & $\begin{array}{r}\text { Mixed } \\
(\mathrm{n})\end{array}$ & $\begin{array}{r}\text { Quantitative } \\
(\mathrm{n})\end{array}$ & $\begin{array}{r}\text { Qualitative } \\
(\mathrm{n})\end{array}$ & $\begin{array}{r}\text { Total } \\
(\mathrm{n})\end{array}$ & $\begin{array}{r}\text { Total } \\
(\%)\end{array}$ \\
\hline North Carolina State & - & - & 2 & 2 & $8 \%$ \\
University (USA) & - & - & 2 & 2 & $8 \%$ \\
Ulster University (UK) & - & - & 2 & 2 \\
\hline
\end{tabular}

Universities that have multiple publications on social entrepreneurship in tourism between 2015 and 2020 are the North Carolina State University in the United States and the Ulster University in the United Kingdom. The doctoral dissertations were carried out through qualitative methods in both universities. 
ToSEE - Tourism in Southern and Eastern Europe, Vol. 6, pp. 1-24, 2021.

E.O. Aksoz, İ.I. Can, E. Mihelj: BIBLIOMETRIC ANALYSIS OF POSTGRADUATE DISSERTATIONS...

In this study postgraduate dissertations focusing on the concept of social entrepreneurship, and the concepts of entrepreneurship in tourism and social entrepreneurship, which have become increasingly important in theory as well as in practice are examined. To make a comparison between countries, Turkey, the United Kingdom, and the United States were included in the study. It was aimed to examine both postgraduate and doctoral dissertations; however, due to the limited access to postgraduate level dissertations in the United Kingdom and the United States, in order not to damage the reliability of the study, the findings of the study were interpreted only based on doctoral dissertations. On the other hand, both postgraduate and doctoral dissertations accessed were included in the Appendix at the end of the study.

\section{Limitations of the research}

The limitation of this research is that only the postgraduate dissertations accessed on the databases are examined. In other words, postgraduate dissertations that cannot be found in the analysed databases cannot be included in the analysis process of the research. In addition, only postgraduate dissertations published in the last five years (2015-2020) were included in the scope of the research, and other scientific sources (articles, papers, books, book chapters, etc.) were not included. Also, unlike Turkey, an online database combining both doctoral and master's theses (or only master's thesis) gather under a single roof could not be reached in the UK or the USA. Detailed information on this is explained in the methodology part of the study. In order to make an accurate comparison between countries, the master's theses reached in Turkey were not included in the research and the research was carried out only on doctoral dissertations.

\section{CONCLUSIONS AND RECOMMENDATIONS}

Although it has been observed that the studies on social entrepreneurship have increased in recent years, it is thought that there are still not enough social entrepreneurship studies in the field of tourism. In addition, the increase in bibliometric studies on both social entrepreneurship and other tourism related fields; and the lack of studies examining social entrepreneurship and tourism at the level of postgraduate dissertations constitutes the starting point of this study.

The study aims to examine postgraduate dissertations published between 2015 and 2020 in Turkey, the United Kingdom, and the United States in the fields of social entrepreneurship, entrepreneurship in tourism and social entrepreneurship in tourism accessed through Proquest Dissertations, YÖK National Dissertations Center, EThOS British Library and EBSCO Dissertations databases via various parameters. The parameters used in the study were determined as "country where the dissertations were prepared, type of the dissertations, publication year of the dissertations, title of the dissertations supervisor, university where the dissertations was prepared, field of study of the dissertations, research method used in the dissertations". In this direction, a total of 126 doctoral dissertations, with 98 in the field of social entrepreneurship, four in the field of social entrepreneurship in tourism, and 24 in the field of entrepreneurship in tourism, were examined. 
ToSEE - Tourism in Southern and Eastern Europe, Vol. 6, pp. 1-24, 2021.

E.O. Aksoz, İ.I. Can, E. Mihelj: BIBLIOMETRIC ANALYSIS OF POSTGRADUATE DISSERTATIONS...

As a result of the study, the availability of 98 doctoral dissertations on social entrepreneurship in the last five years confirmed the view of Sassmannshausen and Volkmann (2013) that social entrepreneurship has reached a certain maturity in literature. Although doctoral dissertations published in the field of social entrepreneurship are quantitatively sufficient, it has been observed that the fields of study are mostly limited by the axis of business and educational sciences. Based on this, it is predicted that social entrepreneurship will go beyond these fields and will start to show its effect in other branches of science over time.

The number of dissertations published on social entrepreneurship in tourism is worrying. Although social entrepreneurship has become a highly accepted subject in business management and education sciences, social entrepreneurship remains a new subject awaiting research in the tourism management department. This is confirmed by Celebi et al. (2020), examining articles on gastronomy tourism and social entrepreneurship being able to access a total of 20 articles; and Sarıbaş et al. (2020), examining the articles on tourism and social entrepreneurship, being able to access a total of 35 articles. Additionally, fields of study related to social entrepreneurship in tourism are determined as tourism management, recreation, and cultural heritage. This situation is similar to the findings of Sarıbaş et al. (2020), who states that most of the research on social entrepreneurship in tourism focus on tourism management. The fact that there is such a large difference in numerical terms between social entrepreneurship studies in other disciplines and social entrepreneurship studies in tourism shows once again the importance of Fu et al. (2019) proposal that researchers in the field of tourism should conduct interdisciplinary work in projects related to entrepreneurship.

Although the number of articles and papers published on entrepreneurship in tourism is quite high, only 24 doctoral dissertations could be accessed in the three selected countries in the last five years. Although the fact that studies are conducted at doctorate level in this field shows that the findings of $\mathrm{Li}$ (2008) and Solvoll et al. (2015), that the theoretical foundations of entrepreneurship in tourism are not established, have become open to falsification, it is thought that the number of postgraduate dissertations in this field can be improved. In addition, there is a six-fold quantitative difference between the fields of entrepreneurship in tourism and social entrepreneurship in tourism. This situation shows that entrepreneurship in tourism is a more researched subject than social entrepreneurship in tourism.

Social entrepreneurship in tourism is a new subject with a major research gap in Turkey, the United Kingdom, and the United States. So much so that only four doctoral level dissertations were accessible in the three countries in the last five years. In other words, the theoretical infrastructure of social entrepreneurship in tourism is quite insufficient. It is apparent that Turkey is lagging the United Kingdom and the United States in the field of social entrepreneurship. While in the last five years, 6 doctoral dissertations on social entrepreneurship were published in Turkey, the number of dissertations published in the United Kingdom and in the United States is 46. Similarly, it is concluded that Turkey should develop itself about tourism entrepreneurship. While in the last five years, two doctoral dissertations in the field of entrepreneurship in the tourism were published in Turkey, 11 each were published in the United Kingdom and in the United States. These findings show that all three areas are current for both developed and developing countries; 
ToSEE - Tourism in Southern and Eastern Europe, Vol. 6, pp. 1-24, 2021. E.O. Aksoz, İ.I. Can, E. Mihelj: BIBLIOMETRIC ANALYSIS OF POSTGRADUATE DISSERTATIONS...

and show the excess of the gaps that need to be filled in the literature. In this context, it is thought that if the researchers and students working in tourism and related fields, expand the topic of entrepreneurship in tourism and focus on social entrepreneurship in tourism, they will make significant contributions to the literature.

\section{REFERENCES}

Akkaşoğlu, S., Akyol, C., Ulama, Ş and Zengin, B. (2019), "Tarım Turizmine Yönelik Hazırlanan Lisansüstii Tezlerin Bibliyometrik Analizi", Journal of Tourism and Gastronomy Studies, Vol. 7, No. 2, pp. 1193-1218. doi: 10.21325/jotags.2019.416

Aksöz, E.O. and Yücel, E. (2020), "Engelli Turizmi Alanındaki Lisansüstü Tezlerin Bibliyometrik Analizi", Türk Turizm Araştırmaları Dergisi, Vol. 4, No. 1, pp. 388-404.

Al, U. (2008), Türkiye'nin Bilimsel Yayın Politikası: Atıf Dizinlerine Dayalı Bibliyometrik Bir Yaklaşım, PhD Tezi, Yayımlanmamış, Hacettepe University Sosyal Bilimler Enstitüsü, Ankara.

Al, U. and Coștur, R. (2007), "Türk Psikoloji Dergisi'nin Bibliyometrik Profili. Türk Kütüphaneciliği, Vol. 21, No. 2, pp. 142-163.

Al, U. and Tonta, Y. (2004), Atıf analizi: Hacettepe University Kütüphanecilik Bölümü tezlerinde atıf yapılan kaynaklar. Bilgi Dünyası, Vol. 5, No. 1, pp. 19-47.

Amini, Z., Arasti, Z. and Bagher, A. (2018), "Identifying Social Entrepreneurship Competencies of Managers in Social Entrepreneurship Organizations in Healthcare Sector", Journal of Global Entrepreneurship Research, Vol. 8, No. 19, pp. 1-14. https://doi.org/10.1186/s40497-018-0102-x

Aydın, B. (2017), "Yükseköğretim kurulu tez merkezinde (YÖKTEZ) yiyecek içecek işletmeciliği alanında kayıtlı bulunan tezlerin bibliyometrik analizi", Disiplinlerarası Akadamik Turizm Dergisi,Vol. 2 , No. 1, pp. 23-38

Aydın, B. and Aksöz, E.O. (2019), "Destination Alanında Yayınlanmış Lisansüstü Tezlerin Bibliyometrik Profili", Journal of Tourism and Gastronomy Studies, Vol. 7, No. 1, pp. 615-636. doi: 10.21325/jotags.2019.381

Başar, M. (2013), Girişimcilik, (Y. Ürper, Dü.) Eskişehir: Anadolu University Açıköğretim Fakültesi Yayını, Anadolu University.

Celebi, D., Pirnar, I. and Eris, E.D. (2020), "Bibliometric analysis of social entrepreneurship in gastronomy tourism", Tourism Review, Vol. 68, No. 1, pp. 58-67. https://doi.org/10.37741/t.68.1.5

Civelek Oruç, M. and Türkay, O. (2017), "Turizmi konu alan lisansüstü çalışmalarının bibliyometrik analizi", in International West Asia Congress of Tourism (Iwact'17).

Compos, V., Sanchis, J.-R. and Ejarque, A. (2019), "Social entrepreneurship and Economy for the Common Good: Study of their relationship through a bibliometric analysis", The International Journal of Entrepreneurship and Innovation, Vol. 21, No. 3, pp. 156-167. https://doi.org/10.1177/1465750319879632

Diodato, V P. (1994), Dictionary of Bibliometrics, The Hawthorne Press, New York.

Dionisio, M. (2019), "The evolution of social entrepreneurship research: a bibliometric analysis", Social Enterprise Journal, Vol. 15, No. 1, pp. 22-45. https://doi.org/10.1108/SEJ-05-2018-0042

Dönmez, S. (2020), Sosyal Girișimcilik, 10 23, 2020 tarihinde Medium: https://medium.com/@donmezselin07/sosyalgi\%CC\%87ri\%CC\%87\%C5\%9Fi\%CC\%87mci\%CC\%87li\%CC\%87k-7d87310ef18e adresinden alınd 1

Ferreira, J.J., Fernandes, C.I., Peres-Ortiz, M. and Alves, H. (2017)., "Conceptualizing social entrepreneurship: Perspectives from the literature", Int Rev Public Nonprofit Mark, Vol. 14, pp. 73-93. doi: 10.1007/s12208-016-0165-8

Fu, H., Okumus, F., Wu, K. and Köseoglu, M.A. (2019), "The entrepreneurship research in hospitality and tourism", International Journal of Hospitality Management, Vol. 78, pp. 1-12. https://doi.org/10.1016/j.ijhm.2018.10.005

Granados, M.L., Hlupic, V., Coakes, E. and Mohamed, S. (2011), "Social enterprise anSocial entrepreneurship research and theory: A bibliometric analysis from 1991 to 2010", Social Enterprise Journal, Vol. 7, No. 3, pp. 198-218. https://doi.org/10.1108/17508611111182368

Güçlü Nergiz, H. (2014), "Türkiye'de lisansüstü turizm tezlerinin bibliyometrik profili (1990-2013)", in VII. Lisansüstü Turizm Öğrencileri Araştırma Kongresi Bildiriler Kitabı, Anatolia Turizm Araştırmaları Dergisi ve Dokuz Eylül University, Aydın, pp. 212-221. 
ToSEE - Tourism in Southern and Eastern Europe, Vol. 6, pp. 1-24, 2021.

E.O. Aksoz, İ.I. Can, E. Mihelj: BIBLIOMETRIC ANALYSIS OF POSTGRADUATE DISSERTATIONS...

Güzeller, C.O. and Çeliker, N. (2017), "Geçmişten Günümüze Gastronomi Bilimi: Bibliyometrik Bir Analiz", Journal of Tourism and Gastronomy Studies, Vol. 5, No. 2, pp. 88-102.

Hotamışl1, M. and Erdem, I. (2014), "Muhasebe ve Finansman Dergisi'nde Yayınlanan Makalelerin Bibliyometrik Analizi", Muhasebe ve Finansman Dergisi (Temmuz), pp. 1-20.

Huang, Y.-L., Ho, Y.-S. and Chuang, K.-Y. (2006), "Bibliometric Analysis of Nursing Research in Taiwan 1991-2004", Journal of Nursing Research, Vol. 14, No. 1, pp. 75-81.

Işık, C., Küçükaltan, E.G., Çelebi, S.K., Çalkın, Ö., Enser, İ. and Çelik, A. (2019a), "Tourism and Entrepreneurship: A Literature Review", Journal of Ekonomi, Vol. 1, pp. 1-27.

Işık, C., Küçükaltan, E.G., Çelebi, S.K., Çalkın, Ö., Enser, İ. and Çelik, A. (2019b), "Turizm ve Girişimcilik Alanında Yapılmış Çalışmaların Bibliyometrik Analizi", Güncel Turizm Araștırmaları Dergisi, Vol. 3, No. 1, pp. 119-149.

Karğın, M., Aktaş, H. and Gökbunar, R. (2018), "Üniversitelerde Sosyal Girişimcilik: Fırsatlar ve Öneriler", Manisa Celal Bayar University I.I.B.F. Vol. 25, No. 1, pp. 155-170.

Kasemodel, M.G., Makishi, F., Souza, R.C. and Silva, V.L. (2016), "Following the trail of crumbs: A bibliometric study on consumer behavior in the Food Science and Technology field", International Journal of Food Studies, Vol. 5, No. 1, pp. 73-83. https://doi.org/10.7455/ijfs/5.1.2016.a7

Koehler, W. (2001), "Information science as "Little Science":The implications of a bibliometric analysis of thevJournal of the American Society for Information Science" Scientometrics, Vol. 5, No. 1, pp. 117-132. https://doi.org/10.1023/a:1010516712215

Kraus, S., Filser, M., O’Dwyer, M. and Shaw, E. (2014), "Social Entrepreneurship: An exploratory citation analysis", Rev Manag Sci, Vol. 8, pp. 275-292. doi: 10.1007/s11846-013-0104-6

Li, L. (2008), "A Review of entrepreneurship research published in the hospitality and tourism management journals", Tourism Management, Vol. 29, No. 5, pp. 1013-1022. https://doi.org/10.1016/j.tourman.2008.01.003

Lluch, J.O., Velasco, E., Lopez, M. and Haba, J. (2009), "Coauthorship and citation networks in Spanish history of science research", Scientometrics, Vol. 80, No. 2, pp. 373-383. https://doi.org/10.1007/s11192008-2089-5

Mort, G.S., Weerawardena, J. and Carnegie, K. (2002), "Social Entrepreneurship: Towards Conceptualisation", International Journal of Nonprofit and Voluntary Sector Marketing, Vol. 8, No. 1, pp. 76-88. https://doi.org/10.1002/nvsm.202

Öğütcü, H. (2015), Girișimcilik Nedir? 10 23, 2020 tarihinde e-girişim: https://egirisim.com/2015/03/18/girisimcilik-nedir/ adresinden alındı

Özdevecioğlu, M. and Cingöz, A. (2009), "Sosyal Girişimcilik ve Sosyal Girişimciler: Teorik Çerçeve", Erciyes University İktisadi ve İdari Bilimler Fakültesi Dergisi, No. 32, pp. 81-95.

Özköse, H. and Gencer, C. (2017), "Bibliometric Analysis and Mapping of Management Information Systems", Journal of Science, Vol. 30, No. 4, pp. 356-371.

Persaud, A., Bayon, M. and Cartmell, S. (2018), "Social entrepreneurship research: A bibliometric analysis", G. Atinc (Dü.), Academy of Management Annual Meeting Proceedings içinde, pp.15510-15550.

Polat, Z.A., Saraçoğlu, A. and Duman, H. (2019), "Harita Dergisi’nin Bibliyometrik Analizi", Harita Dergisi, Vol. 161, pp. 46-56

Pritchard, A. (1969), "Statistical bibliography or bibliometrics?", Journal of Documentation, Vol. 25, pp. 348349.

Rey-Martí, A., Ribeiro-Soriano, D. and Palacios-Marqués, D. (2016), "A bibliometric analysis of social entrepreneurship", Journal of Business Research, Vol. 69, No. 5, pp. 1651-1655. https://doi.org/10.1016/j.jbusres.2015.10.033

Sarıbaş, Ö., Kömürcü, S. and Akbaba, A. (2020), The Concept of Social Entrepreneurship In Tourism: A Bibliometric Analysis for Tourism Literature", Euroasia Journal of Social Sciences and Humanities, Vol. 7, No. 4, pp. 51-59.

Sassmannshausen, S.P., and Volkmann, C. (2013), "A bibliometric based review on social entrepreneurship and its establishment as a field of research", No. 2013-003, Schumpeter Discussion Papers.

Siirt University Ders Notları (2019), Girişimcilik Teknikleri. [Ders notu]. Siirt: Siirt University. 10 23, 2020 tarihinde http://www.siirt.edu.tr/dosya/personel/girisimcilik-teknikleri-ders-notu-siirt201842795924378.pdf adresinden alınd

Smith, L. (1981), "Citation analysis", Library Trends, Vol. 30, No. 83, pp. 83-106.

Solvoll, S., Alsos, G.A. and Bulanova, O. (2015), "Tourism Entrepreneurship - Review and Future Directions", Scandinavian Journal of Hospitality and Tourism, Vol. 15, No. 1, pp. 120-137. https://doi.org/10.1080/15022250.2015.1065592

Sünnetçioğlu, A., Yalçınkaya, P., Olcay, M. and Okan, S. (2017), "Turizm alanında yazıllmıs olan gastronomiye ilişkin tezlerin bibliyometrik profili", Journal of Tourism and Gastronomy Studies, Vol. 5, No. 2, pp. 345-354. doi: 10.21325/jotags.2017.136 
ToSEE - Tourism in Southern and Eastern Europe, Vol. 6, pp. 1-24, 2021.

E.O. Aksoz, İ.I. Can, E. Mihelj: BIBLIOMETRIC ANALYSIS OF POSTGRADUATE DISSERTATIONS...

Şakar, G. and Cerit, A.G. (2013), "Uluslararası alan indekslerinde Türkiye pazarlama yazını: Bibliyometrik analizler ve Qualitative bir araştırma", Atatürk University İktisadi ve İdari Bilimler Dergisi, Vol. 27, No. 4, pp. 37-62.

Tayfun, A., Ülker, M., Gökçe, Y., Tengilimoğlu, E., Sürücü, Ç. and Durmaz, M. (2018), "Turizm Alanında Yiyecek ve İçecek ile İlgili Lisansüstü Tezlerin Bibliyometrik Analizi", Journal of Tourism and Gastronomy Studies, Vol. 6, No. 2, pp. 523-547. doi: 10.21325/jotags.2018.227

TDK (2020), Tez. Sözlük Maddesi. Türk Dil Kurumu. 12 24, 2020 tarihinde https://sozluk.gov.tr/ adresinden alind

Tonta, Y. (2009), Ders Notu. Diğer Araştırma Yöntemleri: Bibliyometri, Atıf Analizi, Yöneylem Araştırması. Hacettepe University. 12 24, 2020 tarihinde

http://yunus.hacettepe.edu.tr/ tonta/courses/spring2009/bby208/bby208-5-bibliyometri.pdf adresinden alınd 1

ULAKBİM (2020), Bibliyometrik Analiz Slkça Sorulan Sorular. 12 23, 2020 tarihinde Tübitak Ulakbim Cahit Arf Bilgi Merkezi: https://cabim.ulakbim.gov.tr/bibliyometrik-analiz/bibliyometrik-analiz-sikcasorulan-sorular/ adresinden alındı

Ulu, S. and Akdağ, M. (2015), "Dergilerde yayınlanan hakem denetimli makalelerin bibliyometrik profili: Selçuk iletişim örneğ",. Selçuk Illetişim, Vol. 9, No. 1, pp. 5-21.

Wang, X., Xu, Z. and Škare, M. (2020), "A bibliometric analysis of Economic Research-Ekonomska Istraživanja (2007-2019)", Economic Research-Ekonomska Istraživanja, Vol. 33, No. 1, pp. 865886. https://doi.org/10.1080/1331677X.2020.1737558

Yılmaz, E. and Sünbül, A.M. (2009), "Üniversite Öğrencilerine Yönelik Girişimcilik Ölçeğinin Geliştirilmesi", Selçuk University Sosyal Bilimler Enstitüsü Dergisi, Vol. 21, pp. 195-203.

Yılmaz, G. (2017), "Restoranlarda Bahşiş İle İlgili Yayınlanan Makalelerin Bibliyometrik Analizi", Seyahat ve Otel İşletmeciliği Dergisi, Vol. 14, No. 2, pp. 65-79. https://doi.org/10.24010/soid.335082

YÖK (2021). Tarihçe. https://www.yok.gov.tr/kurumsal/tarihce. (E.T.: 03.08.2021).

Emre Ozan Aksöz, PhD., Associate Professor

Anadolu University/Tourism Faculty

Tourism Management

Eskisehir, Turkey

+902223350580/2102

ozana@anadolu.edu.tr

İpek Itir Can, MSc., Research Assistant

Anadolu University/Tourism Faculty

Tourism Management

Eskisehir, Turkey

+902223350580/2157

ipekic@anadolu.edu.tr

Ervin Mihelj, PhD Student

University or Rijeka, Faculty of Tourism and Hospitality Management

Primorska 46, p.p. 97, 51410 Opatija, Croatia

ervinmih@gmail.com 